\title{
MAKNA SETIAP BAGIAN PADA RUMAH ADAT SUMBA KABIZZU UMBU DEDO-SUMBA BARAT DAYA DAN PENGARUHNYA DALAM KEHIDUPAN MASYARAKAT SETEMPAT
}

\author{
Gerardus Ouda Ngara \\ Program Studi Arsitektur, Fakultas Teknik, Universitas Dwijendra \\ oudangara021@gmail.com \\ Anak Agung Ayu Sri Ratih Yulianasari, S.T., M.Ars \\ Program Studi Arsitektur, Fakultas Teknik, Universitas Dwijendra \\ gung.gegratih@gmail.com
}

\begin{abstract}
Abstrak
“Dari Sabang sampai Merauke, dari Miangga sampai Pulau Rote.”Demikian sebuah kalimat yang sering terdengar dalam acara Waktu Indonesia Timur (WIT), yang dipandu langsung oleh anak-anak comedian asal Indonesia Timur.Indonesia sebagai sebuah negara kepulauan memang terbentang dari Sabang sampai Merauke.Beda pulau pulau, ragam Bahasa, dan ragam pula budaya dan karakter manusinya.Manusia Indonesia adalah manusia berbudaya.Setiap suku, agama dan dan ras selalu menjunjung tinggi nilai-nilai budayanya masing-masing. Sumba sebagai salah satu pulau bagian selatan di Indonesia pun sangat berbudaya.Bahasanya banyak, rumah adatnya pun sangat unik.Desain rumah ada dengan menara mencakar langit menjadi symbol tersendiri bagi masyarakat Sumba.Rumah adat orang Sumba memiliki nilai eksotik tersendiri.Bahannya sangat alamiah, yakni kayu, alang dan tali hutan.Bahan-bahan ini didesain sedemikian rupa sehingga menghasilkan sebuah rumah dengan sebuah keindahan yang bagus dan sangat eksotik.Di dalam desain sebuah rumah adat berbentuk panggung ini, terkandung di dalamnya prinsip keseimbangan.Ada tempat yang Ilahi (Tingkat 3), ada tempat manusia (Tingkat 2) dan ada tempat bagi hewan piaraan (Tingkat 1).Namun demikian semuanya tetap membentuk sebuah kesatuan dan keutuhan. Allah (Marapu) melihat kehidupan manusia, manusia menjalankan perintah Ilahi dalam kerja sama dengan alam sekitar. Dan desain rumah adat ini sungguh mewakili kolaborasi tri dimensi kehidupan ini. Ada kerja sama yang mengagumkan antara yang insani dan yang Ilahi, Tuhan dan manusia. Allah memintal tali kehidupan manuai, manusia bergerak dalam tata dan nilai Ilahi, dengan cara memabngun kehidupan yang Tuhan berikan. Selalu terdapat norma-norma yang mengatur kehidupan bersama.Dan nilai-nilai itu, tergambar dan terukir pada setiap rumah adat.Ada rumah yang sangat pemali.Hanya para Rato (Imam Marapu) yang layak dan diperkenankan untuk masuk dalam rumah adat ini untuk menjalankan ritual keagamaan.Ada rumah yang merupakan rumah warga, tetapi di dalamnya tedapat koro Marapu (Kamar Marapu).Dan terkadang di rumah ini, selalu digunakan untuk menjalankan ritual keagamaan.Rumah adat orang Sumba ini, sudah memiliki bagian masing-masing. Setiap bagian selalu memiliki arti dan makna tersendiri.
\end{abstract}

Kata Kunci : Manusia, Rumah adat, Sumba, Falsafah

\begin{abstract}
"From Sabang to Merauke, from Miangga to Rote Island." That is a sentence that is often heard in the event of Eastern Indonesia Time (WIT), which is directly hosted by comedians from East Indonesia. Indonesia as an archipelago country stretches from Sabang to Merauke. Different islands, various languages, and also a variety of culture and human character. Indonesian people are cultured humans. Every ethnicity, religion and race always upholds their respective cultural values. Sumba as one of the southern islands in Indonesia is very cultured. The language is many, the traditional house is very unique. The design of the house with a tower clawing the sky becomes a symbol for the people of Sumba. The traditional house of the Sumba people has its own exotic value. The materials are very natural, namely wood, reeds and forest ropes. These materials are designed in such a way as to produce a house with a beautiful and very exotic beauty. In the design of a traditional house in the form of this stage, it contains the principle of balance. There is a place that is divine (Level 3), there is
\end{abstract}


a place for humans (Level 2) and there is a place for pets (Level 1). However, all of them still form a unity and wholeness. Allah (Marapu) sees human life, humans carry out divine commands in cooperation with the natural surroundings. And the design of this traditional house really represents this tri-dimensional collaboration of life. There is a wonderful collaboration between human and divine, God and human. God spins the rope of human life, humans move in divine order and values, by building the life that God has given. There are always norms that govern life together. And those values, are reflected and engraved on every traditional house. There is a very small house. Only the Rato (Imam Marapu) are fit and allowed to enter this traditional house to carry out religious rituals. There is a house that is a resident's house, but inside there is a Marapu koro (Marapu's Room). And sometimes in this house, it is always used to carry out religious rituals. This traditional house of the Sumbanese people already has their respective parts. Each part always has its own meaning and meaning.

Keywords: Human, Traditional house, Sumba, Philosophy

\section{PENDAHULUAN}

\section{a. Latar Belakang}

Budaya bagi manusia itu sendiri adalah tempat di mana ia menyejarah dalam ruang dan waktu. Kehidupannya yang demikian adalah tanda bahwa Ia adalah makluk terbatas. Kehidupannya dalam ruang dan waktu ini bukan tanpa soal. Banyak peristiwa hidup yang terkadang membuat diri manusia terlempar dari situasi normal ke situasi tidak normal.

Sebagai mahkluk yang terbatasdi hadapan persoalan hidup yang ia alami, manusia mengalami dirinya sebagai bagian dari keseluruhan realitasyang tidak seluruhnya dapat ia pahami. Kesadaran ini mengangkat manusia ke dimensi lainyang melampaui batas-batas dirinya. Manusia berhadapan dengan sesuatu yang lain sama sekali (Gea, dkk. 2004:10). Secara periodik ia berhadapan dengan wujud lain yang menjadi perancang kehidupannya. Praksis hubungan itu terjadi melalui ritual keagamaan. Melalui praksis ritual yang dirayakan manusia, secara periodik pada ruang dan waktu tertentu, maka peran atau fungsi dari ritus disesuaikan dengan tempat, waktu dan jenis ritus dilaksanakan. Biasanya praksis ritual ini berhubungan dengan siklus musim, siklus kehidupan maupun peristiwa-peristiwa kehidupan lainnya yang dianggap sakral dan menyibakan campur tangan Yang Ilahi. (Watu Yohanes, 2008: 26-27)

Manusia berkembang dan terus maju mengikuti perkembangan zaman. Dari perkembangan ini kadang manusia melupakan apa yang menjadi akar dari sebuah kebudayaan. Manusia senantiasa kuat ketika manusia berefleksi akan sejarah perjalanan hidupnya. Bila manusia terlepas dari akar kehidupannya maka ada begitu banyak budaya lokal yang terlupakan, yang sebenarnya sangat berguna dalam pembentukan perjalanan hidup selanjutnya (Daeng, 2008:38)

Dari perspektif fenomenalogis manusia adalah makhluk berbudaya, ens culturale. Manusia berjuang mengembangkan diri menurut forma spiritual yang melekat pada kodrat dirinya sebagai makhluk spiritual. (Saku, 2004:53). Untuk mampu mendefenisikan dan merealisasikan diri, manusia perlu meretas jalan pengembangan diri yang integral. Untuk itu mutlak perlu suatu kebudayaan yang integral, yaitu kebudayaan yang sanggup memelihara dan membangun manusia secara keseluruhan. Salah satunya adalah manusia perlu menjaga setiap sejarah kehidupannya serta memampukan ia untuk menjaga nilai-nilai luhur yang terkandung dalam budaya yang diwariskan secara turun-temurun oleh nenek moyang melalui peribahasa, tradisi dongeng kebijaksanaan, mitos, ritual, simbol, ingatan-ingatan kolektif,adat kebiasaan dan bahasa tanda serta salam penghormatan (Sutrisno, 2009:84). 
Sumba adalah sebuah daerah dengan budayanya yang sangat kental. Berbicara tentang Sumba, tentu tak lepas pisah dalam hubungannya dengan kepercayaan asli yakni Marapu. Marapu bagi masyarakat Sumba, merupakan jantung dan nyawa dari semua perjuangan dan hidup manusia (Bamualim, 2009:35). Dalam klasifikasinya, Marapu terdiri dari beberapa bagian. Menurut Dr. Petrus Ngongo Tanggu Bera, MSi, dalam sebuah tulisannnya mengenai Maringi: Roh Orang Sumba Marapu (Gregor Neonbasu, SVD, Prospektif Pembangunan: 2013) mengklasifikasikan Marapu dalam tiga kategori yakni berdasarkan status, tempat dan fungsi.Berdasarkan status, ada Marapu Kalada (Marapu Besar), yang dalam derajat tertentu mendekati status pencipta. Berdasarkan tempat ada Marapu Loda-Marapu Pada (Marapu Alam Raya), berfungsi untuk mengawal alam raya (ruang), Marapu Magho (Pelindung), berfungsi melindungi tanah, hutan dan air dari perusakan manusia atau bencana lain, Marapu Wanno (Kampung), bertugas mengawal kampong dari serangan musuh, Marapu $\mathrm{Kabizzu/Uma} \mathrm{(Suku/rumah)} \mathrm{bertugas} \mathrm{mengawal} \mathrm{warga} \mathrm{suku/rumah.}$

Rumah menjadi sangat penting bagi kehidupan manusia.Bahkan roh alam semesta pun memiliki rumah. Bagi masyarakat sumba, rumah menjadi muara terakhir dari semua perjalanan hidup (Monje, 2009: 79). Semua kegiatan berawal dan akan kembali menuju rumah. Ada rumah dunia ini, yang sifatnya sementara, ada rumah di dunia seberang yang adalah rumah keabdian.Rumah abadi ini dikenal dengan namaWanno Kalada (Kampung besar).

Dalam hubungan dengan rumah, dalam masyarakat sumba dikenal dengan dua istilah Umma Kalada dan Kareka Oma (Rumah Kebun). Umma Kalada dalam pemaknaannya lebih dikenal dengan istilah rumah besar, rumah adat, di mana rumah ini menjadi rumah yang diperuntukkan bagi Marapu.Rumah ini letaknya berada di dalam kampung besar, dan itu adalah kampung suku, sedangkan kareka oma (Rumah kebun).Biasanya istilah ini dilekatkan dengan rumah warga yang merupakan rumah tinggal.Setiap rumah memiliki marapu pelindungnya, dan setiap suku memiliki rumah adatnya masing-masing.Antara rumah adat dan rumah kebun ini, dalam pembuatannya juga berbeda.Berbeda dari cari fungsinya, juga berbeda dalam cara pengerjaannya. Namun desain atau gambarnya, hampir sama. Untuk kajian ini, maka penulis pada kesempatan ini ingin menelaah rumah budaya Sumba ini dalam sebuah tulisan kecil ini.Sebagai putera asli Sumba, penulis merasa perlu untuk memperkenalkan sumba ke dunia luar, termasuk rumah adat Sumba. Semoga tulisan ini sungguh berguna untuk generasi sumba selanjutnya dan seua orang yang menyukai alam dan rumah adat Sumba.

\section{b. Rumusan Masalah}

Masalah utama yang perlu dikaji dalam kesempatan ini adalah

a. Bagaimana desain Rumah Adat Sumba?

b. Apa fungsi setiap bagian yang melingkupi sebuah Rumah Sumba?

\section{c. Tujuan Penelitian}

Tujuan dari tulisan ini adalah:

a. Untuk mengetahui desain rumah adat sumba .

b. Untuk Mengetahui Fungsi Setiap Setiap Bagian Yang Melengkapi Rumah Adat Sumba.

\section{METODOLOGI}

Metode yang digunakan dalam penelitian adalah:

a. Studi kepustakaan, mencari informasi dari sumber lain yang bisa mendukung tulisan ini.

b. Mengadakan wawancara dengan beberapa tokoh adat yang paham secara baik dan benar tentang rumah adat Sumba. Wawancara dilakukan melalui telephone genggam. 
Kondisi ini merupakan efek pandemic covid-19 yang masih meresahkan, sehinggapenulis hanya bisa berkomunikasi dengan para narasumber via telephone.

\section{TINJAUAN TEORI}

\section{a. Rumah Adat}

Pater Robert Ramone, CSsR, dalam sebuah tulisannya mengenai rumah adat Sumba mengatakan sebagai berikut

"Rumah Adat dengan menara tinggi dan batu kubur di depan rumah merupakan sebuah pemandangan yang biasa dan umum di Pulau Sumba. Bagi orang Sumba, rumah tidak sekedar sebagai tempat tinggal, demikian juga dengan kuburan, bukan sekedar onggokan batu tak bernyawa.Rumah adat dan batu kubur menjadi ciri atau identitas masyarakat Sumba.Tipikal ini menggambarkan hidup dan perjuangan mereka di dunia ini serta tujuan ziarah hidup mereka yang berakhir yakni kehidupan barusetlah hidup di dunia ini”.(Majalah Warta Flobabamora, ed. 80- VIII-2020).

Pernyataan ini amat sangat dalam dan bermakna. Sebagai mana yang sudah penulis ungkapkan pada bagian pendahuluan, bahwa hidup manusia bagi orang Sumba tidak akan berhenti di dunia ini tetapi akan berlanjut di kehidupan nanti. Di sana akanada persatuan antara keluarga dan sesama anggota suku dalam satu marga. Kehhidupan di dunia ini akan berlanjut di sana dalam cara yang sama. Desain rumah adat dengan latar depan batu kubur di depan rumah, menjadi sangat penting dan bernilai filosofis, sosiologis dan teologis. Ada kekinian atau kenyataan yang sedang dijalani saat ini, tetapi juga ada harapan yang tersembunyi di balik ruang iman dan agamawis akan adanya kehidupan baru di akhirat nanti. Selain itu, ada comunio yang tercipta antara orang yang mati dan orang yang hidup.Sekalipun raga orang mati telah tiada, tetapi jiwa mereka selalu ada di sekitar dan menjadi pelindung bagi tiap orang, tiap rumah dan bahkan tiap suku.

Pada umumnya, rumah adat Sumba selalu dibangun di atas perbukitan yang dikelilingi pagar batu yang rapih tersusun, dan dilingkapi dengan dua pintu gerbang, sebagai pintu keluar dan pintu masuk.tujuan bangunan perkampungan orang Sumba di atas bukit, demi keamanan. Situasi perang antara suku waktu itu menjadi antisipasi keamanan dan keselamatan anggota suku dan suku itu sendiri.

P. Robert Ramone mengatakan bahwa "rumah adat bagi orang Sumba merupakan rumah suku sekaligus menjadi identitas atau jati diri para warganya. Dengan kata lain, tidak memiliki rumah adat, sama dengan tidak memiliki jati diri. " atas dasar inilah maka, setiap warga suku memiliki tugas dan tanggujawab untuk melihat dan membangun rumah adatnya masing-masing. Setiap warga suku akan selalu mengadakan musyawara untuk mufakat dalam mebangun rumah. Ketika rumah itu dalam keadaan rusak dan butuh diperbaiki, warga suku dalam pimpinan dan kendali Rato Marapu (Imam adat), akan selalu melangsungkan pertemuan untuk melihat kondisi rumah suku.

\section{b. Rumah Kebun}

Istilah rumah kebun dipakai untuk membedakan fungsi dengan rumah adat.Rumah kebun merupakan rumah warga atau keluarga. Rumah kebun ini tersebar dan berbaur dengan warga lain di kampong-kampung dan di desa-desa, membentuk sebuah dusun (kali mbyatu). Rumah kebun dalam pengerjaannya tidak melalui proses ritual adat yang rumit. Rumah 
kebun ini, juga bisa mengikuti desain yang sedikit modern sesuai dengan kebutuhan dan keinginan setiap kepala keluarga yang menghuni rumah itu.Untuk rumah warga yang menggunakan desain tradisional dengan bahan utama, alang-alang, kayu, selalu mengikuti desain rumah adat, tetapi dalam ukuran yang lebih kecil. Desainnya sama dengan rumah adat, tetapi fungsinya berbeda.

\section{HASIL DAN PEMBAHASAN}

Studi kasus dalam pengambilan data berada di kampung adat Dappa Elu, Desa wali Ate Kecamatan Wewewa Barat Kabupaten Sumba Barat Daya.
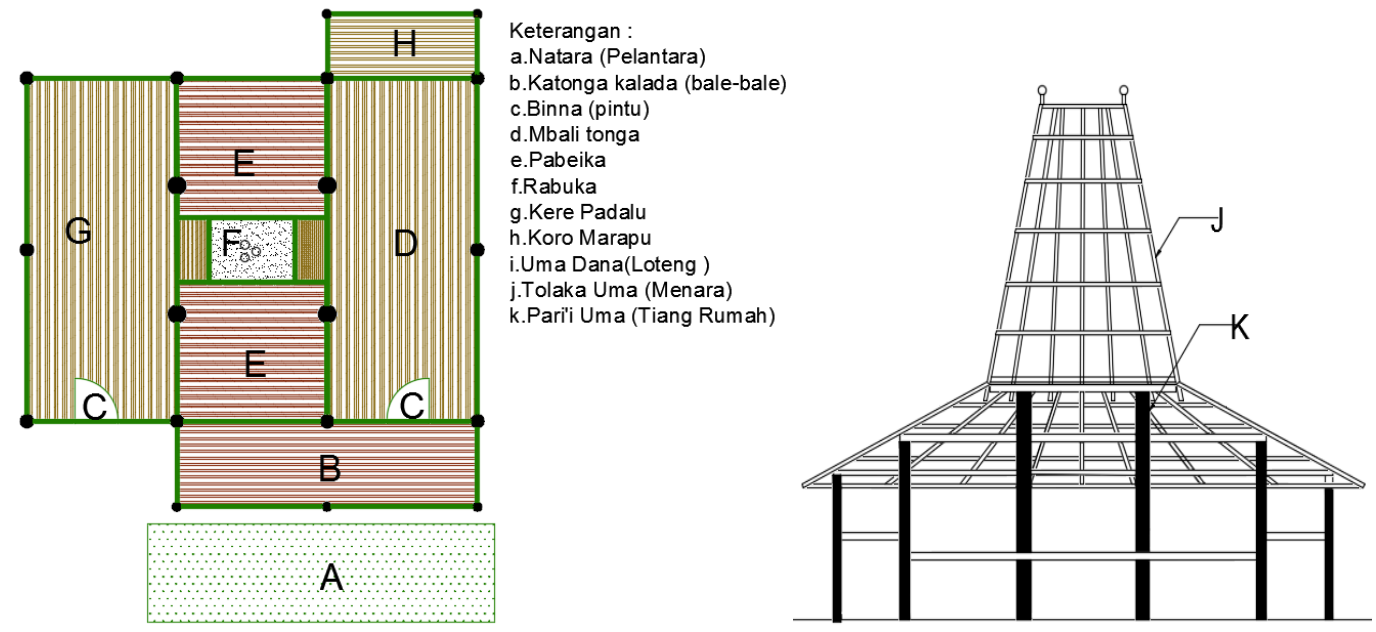

Gambar 1. Lay Out rumah kampung adat dappa elu Sumber: dok.pribadi (2020)

a. Natara (Pelataran)

Hal paling pertama yang akan kita temui, saat memasuki kampong orang Sumba adalah adanya sebuah pelataran. Pelataran ini biasanya berbentuk bulat karena rumah-rumah warga dibangun membentuk sebuah lingkaran penuh.Fungsi pelataran sebagai tempat dilangsungkannya atraksi seni-Budaya-atau pesta adat lainnya.Di tengah-tengah pelataran itu biasanya ada natara paddu yang terbuat dari batu atau kayu, yang merupakan symbol dan resepsetasi marapu wanno.Symbol ini menjadi lambang Marapu penjaga Kampung.

Selain itu, ada pula hamparan batu kubur yang melambangkan adanya kehidupan di akhirat. Batu-batu kubur selalu di depan rumah karena orang Sumba memiliki keyakinan dan filosofi sendiri bahwa selalu ada persatuan antara orang hidup dan orang mati. Orang mati akan selalu dikunjungi dengan mempersembahkan sirih pinang. Kubur mereka selalu dibersihkan.

b. Katonga Kalada (Bale- Bale)

Di bagian depan rumah, terletak sebuah bale-bale besar (Katonga). Fungsi bale-bale ini adalah sebagai tempat menerima tamu, baik tamu yang sifatnya special maupun tamu yang tidak special.Bale-bale ini dibuat dengan ukuran yang sangat minimalis.Di bagian kiri dan kanan, terdapat bale-bale kecil yang dikenal dengan 
istilah katongo mbodo.Biasanya kedua tempat kecil ini digunakan untuk istirahat santai pada siang hari setelah pulang dari kebun atau dari tempat di luar rumah.

c. Binna (Pintu)

Setiap rumah, selalu memiliki pintu.Selain sebagai tempat keluar masuk, namun pintu juga memiliki arti sebagai symbol keterbukaan pemilik rumah dengan dunia luar.Biasanya pintu di sini ada dua jenis yakni sebelah kiri dan sebelah kanan rumah.Pintu sebelah kiri rumah, merupakan pintu yang melambangkan maskulinitas.Artinya pintu ini hanya dilalui oleh kaum pria (Binna Mbali Tonga). Orang Sumba zaman dulu, sudah tahu ketika mengunjungi sebuah rumah, jika ia adalah laki-laki, maka ia akan lalui pintu sebelah kanan. Sedangkan pintu sebelah kiri rumah adalah pintu symbol perempuan (Binna Kerepandula). Sama halnya, seorang tuan rumah, ketika keluar dan masuk rumah, harus melalui pintu kerepandalu jika ia adalah perempuan, demikian sebaliknya jika ia adalah seorang laki-laki. Seorang perempuan dilarang melewati pintu laki-laki karena dianggap sangat pemali., seblaiknya demikian.

d. Mbali Tonga

Rumah orang Sumba pada dasarnya berbentuk panggung. Setelah melewati pintu masuk sebelah kiri rumah, kita akan menemukan Mbali tonga. Temapt ini berfungsi sebagai tempat berlangsungnya musyawara penting seperti acara adat kawin mawin, ritual keagamaan, dan berbagai jenis musyawara lainnya yang melibatkan banyak orang. Selain itu, jika ada yang meninggal, maka jenazah orang itu akan diletakkan di tempat ini.

e. Pabeika

Pabeika artinya tempat tidur. Pabeika di sini ada dua jenis, yakni di bagian depan dan bagian belakang rumah, yang dipisahkan oleh rabuka(Tempat memasak nasi). Pabeika ini terbuat dari bilahan bambu yang dibelah kemudian diikat dengan tali (uwe), dengan cara dianyam. Tempat ini didesain sedekian rupa sehingga dapat memberikan kenyamanan bagi penggunanya. Biasanya ketika akan digunakan saat tidur, pabeika akan dialas dengan tikar (Teppe).

f. Rabuka

Rabuka artinya tempat memasak nasi.Rabuka didesain dengan ukuran segi empat. Di dalamnya diletakkan tia tunggu yang terbuat dari batu. Ketiga tungku ini tidak sembarang dipasang. Satu di sebelah mbali tonga, dan duanya di sebelah depan dan belakang rumah sedikit menyamping. Ketika tungku-tungku ini ditanam dan diresmikan sebagai alat untuk memasak nasi, selalu dibuatkan ritual khusus berupa satu ekor ayam dipersembahkan kepada leluhur. Jika suatu ketika salah satu tungku ini rusak oleh karena termakan usia, maka untuk menggantinya harus mengadakan ritual kecil. Rabuka menjadi tempat menanak nasi, tempat setiap manusia memperoleh kekuatan.Rabuka yang baik juga menentukan hidup penghuni rumah.Karena itu, hokum keseimbangan selalu diperhatikan pula dalam mendesain hal ini.

g. Kere Pandalu 
Di setiap rumah adat, selalu ada yang namanya Pandalu.Pandalu adalah sebuah wadah yang terbuat dari periuk tanah, yang dipakai untuk mengisi air.Air yang diisi didalamnya adalah yang ditimba dari sumber mata air. Air yang lama tersimpan di dalam pandalu, semakin lama akan semakin sejuk dan enak. Pandalu ini diletakkan di bawagi sudut rumah berlawanan dengan Mbali tonga, di mana semua aktivitas masak dan memasak terjadi. Boleh dikatakan bahwa kere pandalu adalah tempatnya kaum perempuan menjalankan aktivitas masak memasak.Pada saat makan, air dari pandalu selalu dicedok untuk diberikan kepada anggota rumah tangga.

h. Koro Marapu

Di setiap rumah adat ada yang dinamaka Koro Marapu.Koro artinya kamar, Marapu artinya yang tersembunyi.Jadi secara harafiah, koro Marapu artinya kamar yang tersembunyi.Namun yang dimaksudkan di sini adalah kamar bagi tempat penyimpanan benda keramat, yang melambangkan kehadiran marapu.Tempat ini tidak dibuka sembarangan oleh semua orang, melainkan hanya oleh imam marapu suku, yang berasal dari suku itu.Tuan rumah sekali pun tidak memiliki hak dan wewenang untuk membuka apalgi masuk ke dalamnya.Tempat ini dianggap sangat pemali, sacral karena merupakan tempat berdiamnya roh Marapu.

i. Uma Dana (Loteng)

Uma artinya rumah, dana artinya Dalam. Uma danamerupakan loteng yang terdapat di dalam rumah.Loteng adalah tempat penyimpanan bahan makanan sebagai bekal bagi pemilik rumah itu.Pada umumnya ditempatkan di sini adalah semua hasil kebun yang merupakan jerih payah mereka.Boleh dikatakan bahwa loteng menjadi tempat diletakkannya lumbung makanan yang barusan dipanen seperti padi dan jagung.Loteng dibuat dengan ukuran persegi empat mengikuti ukuran rumah. Bahan dasar yang digunakan adalah belahan bamboo, belahan batang pinang, yang diatur sedemikian rupa sehingga tampak begitu rapih.

Orang Sumba pada dasarnya memiliki kebiasaan mengadakan pesta adat. Satu filosofi yang sering muncul adalah bila sebuah keluarga, atau sebuah suku mengadakan pesta (Woleka), maka ia harus lihat ke atas dan tengok ke bawah. Lihat ke atas artinya apakah loteng itu memiliki persediaan lumbung makanan yang cukup?Tengok ke bawah artinya, apakah kandangnya berisi hewan yang cukup?Dalam sejarah peradaban Sumba, Filosofi ini sangat kuat mendarah daging dala kehidupan orang Sumba Zaman dulu. Namun filosofi ini, seiring perjalanan waktu, mulai memudar, berharap ke depan, filosofi ini tidak hilang.

j. Tolaka Umma (Menara)

Dalam membangun sebuah rumah, orang sumba memiliki cara berpikir dan falsah tersendiri. Hukum keseimbangan sungguh diperhatikan. Menara rumah yang didesain menunjuk langit dengan panjang menara sekitar 7 (Tujuh) Depa, menggambarkan akan pengakuan eksistensi Ilahi. Pengakuan adanya wujud tertinggi atau Tuhan.Di sini ada sebuah istilah yang di sebut dengan Tanggu Marapu La Hindi (Robert Ra Mone, Ibid).Di atas bubungan rumah terdapat dua sudut, kiri dan kanan.Sudut yang satu di beri patung pria, dan sudut yang satu diberi patung perempuan (Kodi).Selain pemberian patung pria dan wanita, di wilayah wewewa, kedua sudut ini menggunakan periuk tanah.Yang menggambarkan symbol kesuburan dan kesejahteraan. Periuk tanah sebagai mana menjadi sarana untuk menanak nasi, 
dengan posisi muka menghadap ke atas saat memasak, maka dengan memasangnya secara terbalik di atas sudut rumah, menggambarkan, sumber kesejahteraan berasal dari wujud tertinggi, yakni dappa tekki ngara - dappa suma tamo (Yang tidak disebut namanya - dan tidak diucapkan gelarnya).

k. Pari'i uma (Tiang Rumah)

Struktur rumah adat Sumba terdiri dari empat tiang utama.Keempat tiang ini terbuat dari kayu yang sangat kuat dengan ukuran yang besar.Fungsinya untuk menyangga konstruksi atap menara.Di atas keempat tiang rumah ini dibuatlah sejenis piringan kayu, yang menambah keindahan dan juha melambangkan symbol kesakralan rumah tersebut. Biasanya di atas tiang ini, juga dibuatlah ukiran-ukiran (urrata) sesuai dengan nama suku rumah tersebut.

\section{PENUTUP}

\section{Kesimpulan.}

Desain rumah adat sumba sangat unik dimam rumah adat sumba identic denga menarah yang merupakan simbol dari masyarakat sumba khususnya masyarakat di kampung adat dappa elu,desa wali ate kecamatan wewewa barat kabupaten sumba barat daya.Desain rumah adat sumba terdiri dari Natara yang berfungsi sebagai tempat dilangsungkan antraksi seni budaya atau pesta adat,Katonga kalada( Tempat Menerimah Tamu), Binna (Pintu) tempat keluar masuk yang melambangkan keterbukaan pemilik rumah, Bali tolanga (tempat bersangsungnya musyara penting), pabeika (Sebagai Tempat Tidur ), Rabuka (Tempat Memasak), Kerepadalu (merupakan sebuah wadah menampung air), Koro marapu(sebagai tempat penyimpaan barang keramat ), Umma dana (Loteng) yang menjadi tempat penyimpanan makanan) dan Pari'i Uma (Tiang Rumah ) yang berfungsi untuk menyangga konstruksi bangunan rumah.

\section{Saran}

Setelah mengkaji dan melihat keadaan rumah adat orang sumba, beberapa hal yang usulkan:

- Untuk Para Rato

Supaya masyarakat adat, terlebih para rato sungguh melestarikan kearifan lokal yang ada ini, dengan tetap mempertahankan eksistensi rumah adat Sumba.

- Untuk Pemerintah Sumba Barat Daya

Supaya Pemerintah dalam kerja sama dengan para Rato, bisa melihat rumah adat sebagai icon wisata yang perlu dipertahankan nilai kesakralannya. Karena itu, wajib sifatnya ada hutan yang tetap dijaga.Kondisi saat ini, hamper banyak rumah adat yang sudah didesain secara modern oleh karena kekurangan bahan seperti kayu, alang dan rotan sebagai bahan dasar rumah adat Sumba. Ini sungguh penting dan mendesak karena hamper saat ini terdapat pembakaran hutan dan padang yang merupakan lumbung bahan bangunan rumah adat.

- Kepada Masyarakat Sumba (Anggota Suku)

Supaya setiap anggota suku atau warga, harus menghidupkanSens of belonging (Rasa memiliki) dalam dirinya dalam memelihara Rumah Adat ini. Jika demikian maka praktek membakar padang dan hutan akan dihilangkan. Ciptakan budaya malu untuk setiap pikiran negatif yang tidak mau menjaga kelestarian alam dan rumah adat kita.Mari 
bersama menjadi agen yang sungguh bertanggungjawab atas setiap kearifan lokal yang ada.

\section{DAFTAR PUSTAKA}

Atosokhi Gea,Antonius,dkk. 2004. Relasi Dengan Tuhan. Jakarta :PT.Gramedia.

Bamualim, Anisah Umar. 2009. Profil Budaya Sumba Barat. Waikabubak: Dinas Kabupaten Sumba Barat

J. Daeng, Dr. Hans. 2008. Manusia, Kubudayaan dan Lingkungan. Yogyakarta: Puskata Pelajar

Sutrisno, Mudji. Ranah-Ranah Kebudayaan. 2009. Yogyakarta: Kanisius.

Monje, Jorge, dkk, 2009. Menelusuri Sumba Pulau 1000 Kampung adat, Dalam Paradiso Timur Raya Comunications (ed). Waikabubak: Dinas Kebudayaan dan Pariwisata Sumba Barat.

Vianey, Watu Yohanes. 2008. Representasi Ilahi Dan Insani Dalam Entitas Ritus Sa'o Ngaza Di Kampung Guru Sina, Kabupaten Ngada, Flore. Disertasi.

Ra Mone, Robert .2020.Rumah Adat Sumba-Rumah Peradaban.Majalah Warta Flobomora.

Saku, Dominikus. Memanusia Lewat Membudaya. 2004. Integritas Diri: BagaimanaMembangunnya dalam VERITAS, Buletin Seminari Tinggi Santo Mikhael, Penfui-Kupang. 